\title{
Blood on the Rock: Cather's Southwestern History
}

\author{
T. Austin Graham*
}

The history major is a bit of a gut at Hamilton University, and fiction is apparently to blame. Professor Horace Langtry, whose specialty is "supposed to be American history," panders to the undergraduates by assigning them novels and crediting "the time spent in perusing 'The Scarlet Letter' to Colonial history, and 'Tom Sawyer' to the Missouri Compromise" (Professor's House 55-56). Those who want to do more demanding work are better off studying under Professor Godfrey St. Peter, who holds a chair in European history and finds the "collateral reading" in Langtry's classes to be "lax" (56). Unlike his literary-minded colleague, St. Peter maintains his discipline's discipline and guards its borders. Yet even he is not so traditional a historian as he might seem: indeed, he was nearly fired in his younger days because "he was carrying on another line of work than his lectures, and was publishing books that weren't strictly text-books" (Professor's House 56-57). Langtry and St. Peter have been feuding over the department's curriculum for years, but each man has run afoul of professional standards, and neither seems entirely committed to history as such.

This dispute, and the larger question it raises about whether novelists and historians are capable of working toward a common intellectual purpose, is at the heart of The Professor's House, Willa Cather's 1925 tale of a distinguished scholar's decline into apathy and enervation. She published it just before making a turn to the past in her fiction - of the five novels she wrote during the rest of her life, three were historical - and the story of Professor St. Peter was an opportunity for her to consider the basic methodological problems that such a turn would present. What are the guiding principles, she seems to ask, of serious historical study and effective historical

\footnotetext{
*T. Austin Graham is an assistant professor of English and Comparative Literature at Columbia University. He is the author of The Great American Songbooks: Musical Texts, Modernism, and the Value of Popular Culture (2013). His current project is a study of US historical fiction in the twentieth century.
} 
narration, and how far can historical fiction go in following them? The 1920s were a time of intense research and academic engagement for Cather, and she was so invested in becoming a better historian in those years that she may have modeled St. Peter on one of the leading scholars of her day. Yet she never lost sight of how her encounters with history could make her a better novelist, as well. In a revealing passage that she eventually cut from the final draft of The Professor's House, Cather expands upon St. Peter's reasons for banning fiction from his classes, arguing that doing so is as healthy for art as it is for the historical profession:

Certainly none of the great English novelists took "courses" in the novel in their undergraduate days. Pupils and masters were engaged with sterner stuff. It was supposed that a wide reading in the Greek and Latin writers gave a young man the best possible training for the study of other literatures, or for the profession of letters, and that theory seems to have worked out very well. The perfecting of classical scholarship had its advantages for the undergraduate, and the revolt from scholarship, the bold plunge into something intimate and personal, had great advantages, - - had indeed, something of the fire and exaltation of revolution. (Professor's House TS N.pag)

Historical study, like the classics, may be "sterner stuff" than fiction, but it can also be a servant to it, for its scholarly rigor is capable of inspiring "revolt," "revolution," and, eventually, a greater art than had been possible before. And while a novelist like Cather might never have been capable of writing a book that a professor like St. Peter would assign to his students, historical labor could still kindle "the fire and exaltation" of her literary achievement.

Two years later, Cather published her meditative, episodic novel Death Comes for the Archbishop (1927), one of the most explicit and successful attempts at merging the disciplines of history and fiction in all of American letters. Considered as a study of the past, it was a remarkable work. It told stories that up to that point had been relatively neglected, bringing readers to the Southwestern corner of North America and relating incidents of local lore from as far back as 1540 . It challenged Americans to reimagine their history as beginning not with the English colonies at Plymouth and Jamestown in the seventeenth century, but with the Spanish conquest a hundred years before. It attended to peoples who had been all but dismissed in most previous histories of the US-Native Americans, Mexicans, and Catholics. And it may well have been the best-researched historical novel that the nation had ever seen. Cather traveled to and did on-the-ground work at the places where she would situate her characters; she consulted an 
[B]y writing a history that was intimate in scope and resistant to easy interpretation, Cather pioneered a methodology that has much to offer contemporary scholars of US imperialism, some of whom have urged the field to take a similarly inward turn. (5) impressive number of sources before and while she wrote; she was ecumenical in her reading, taking equal interest in scholarly tomes and florid travel guides; and she exposed herself to thinkers across the ideological spectrum, from white supremacists to advocates for displaced tribes. With Death Comes for the Archbishop, Cather surveyed a historical field in something close to its entirety, helped fill a silence in the scholarly conversation, and arrived at conclusions that only the most farsighted academics had reached as of 1927.

If Cather published a work of serious history in Death Comes for the Archbishop, however, it was one that could only have been effective in the form of literary fiction. In its barest historical outlines, the novel chronicles the expansion of empires, both Spain's after 1492 and the US' after 1848. Unsurprisingly, it is also a record of military subjugation, showing that a people's land can never be taken without force, regardless of when or by whom the attempt is made. But for all the importance of the novel's hard facts-the incursions it charts, the atrocities it exposes, the silenced voices it listens for-its most distinctive achievement is its portrait of the nineteenth-century American mind, especially that mind's desire to make peace with its own belligerence. Fiction gave Cather access to inner varieties of history that more conventional historical writing would not have allowed, and as a consequence, she could demonstrate not just that the US past had been bloody, but also that its violence had depended on the unique ability of Americans to reconcile themselves to it.

Death Comes for the Archbishop studies the US' expansion through the eyes of a single man, with the novel's view of history constantly refracted by his insights, judgments, and perhaps most important of all, failures of vision. What Cather's protagonist does not see, think, or realize in the novel is as historically significant as what he does, and her decision to write in this oblique manner came at the cost of clarity: critics have frequently been unsure what they are meant to conclude from her private, experiential portrait of empire. But by writing a history that was intimate in scope and resistant to easy interpretation, Cather pioneered a methodology that has much to offer contemporary scholars of US imperialism, some of whom have urged the field to take a similarly inward turn. Amy Kaplan has asked us to consider how imperialism was a "way of life" as well as a matter of foreign policy in the nineteenth century (14), while Susan Gillman has encouraged us to explore the contradictions of the nation's imperial discourse, and especially the "contortions and gyrations" of thought that have allowed Americans of all eras to avoid noticing "the nakedness of our own imperial body" (202). Few texts answer these calls better than Death Comes for the Archbishop, which among other things meditates on how Americans shield themselves from troubling knowledge and absolve themselves from crimes that the state commits in their names. 
Moreover, the novel shows how such historical investigations can be enriched by the unique affordances of literary form: without unreliable narration, symbolic misdirection, and other subtle instruments of language, Cather could not have registered so effectively the vague disturbances and fleeting doubts that haunt the citizens of her imperial nation. Cather may have set out to be a historian of American evasiveness in the days of Southwestern empire, but in the process, she also suggested that only a historical novelist could have told the story.

Cather's literary history began with Godfrey St. Peter, a scholar whose life and work anticipated the direction that her own writing would take in Death Comes for the Archbishop. He is in a state of depression when readers meet him in the first chapter of The Professor's House, and the novel's spare, almost existential plot finds him mourning the death of a favorite student and growing ever more withdrawn from his family. If St. Peter's private life is full of sadness, though, his professional one is enormously satisfying. He enjoys an international reputation and has won various accolades for his Spanish Adventurers in North America, an eight-volume history that required 15 years of labor and research expeditions in Europe, Mexico, and the Southwestern US. Cather never quotes from Spanish Adventurers or summarizes its argument, and says very little about the story it tells. But she does hint at the shape of St. Peter's career and encourages readers to think of it as being in harmony with her own. Indeed, Cather appears to have imagined St. Peter as a kind of academic double, for in 1925, the two writers were roughly the same age, had published the same number of books, and shared a habit of working in cramped sewing rooms. ${ }^{1}$ And because Cather was about to compose her own account of Spanish North America, an investigation of St. Peter's historical methods and scholarly convictions can also help illuminate hers.

Cather makes clear that if one were able to read Spanish Adventurers, it would make for a unique experience. Here is one of her rare descriptions of the project, establishing St. Peter as a confident, unconventional historian:

For all the interest the first three volumes awoke in the world, he might as well have dropped them into Lake Michigan. They had been timidly reviewed by other professors of history, in technical and educational journals. Nobody saw that he was trying to do something quite different - they merely thought he was trying to do the usual thing, and had not succeeded very 
well. They recommended to him the more even and genial style of John Fiske. (33)

Cather goes on to say that the fourth, fifth, and sixth volumes of Spanish Adventurers earned St. Peter greater attention and that the seventh and eighth made him renowned. Beyond that his scholarship remains mysterious, an intertext for the novel that can never be consulted directly.

What more can be assumed about St. Peter's elusive history, given how little else Cather reveals about it? Thanks to clues left throughout The Professor's House, a great deal. It probably takes a sober view of its eponymous adventurers, and a sympathetic one of the Native Americans they encountered, killed, displaced, enslaved, and converted in the fifteenth, sixteenth, and seventeenth centuries. It presumably strikes a balance of objective observation and aestheticized, even literary narration, particularly in its later volumes. It likely reads as the work of a man who has lived outside of libraries, with its account of the past enriched by its author's travels and experiences. And above all else, St. Peter must think of Spanish Adventurers as "something quite different" because it crosses generally accepted borders and divisions, whether between racial groups, academic disciplines, generic forms, or historians and their materials.

Consider first what Spanish Adventurers most decidedly is nota work aspiring to the "even and genial style of John Fiske." One of the most famous practitioners of evolutionary history at the turn of the twentieth century, Fiske had authored several popular books arguing that human civilization, led by the US, was on a path toward ever-greater sophistication and ultimate perfection. A profound racial chauvinist, he believed that Anglo-Saxons were "destined to shape the future of the world" because they possessed a "superior capacity" for Darwinian competition (2: 569). And when St. Peter's first, wrongheaded reviewers recommended that he adopt Fiske as a scholarly model, they were surely thinking of his 1892 work The Discovery of America, a history of Spain's first contact with a "barbaric" continent whose people had not yet progressed out of "the stone age of human thought" (1: vii-viii).

Looking back on this period, Fiske saw a time of miracles. The Spanish explorers, he wrote, had voyaged not just across an ocean to reach America, but across millennia as well. When they arrived, they discovered primordial humans whose evolution had lagged behind theirs, with the natives still stuck "in stages of development similar to those of our ancestral societies in the Old World long ages before Homer" (1: vii-viii). This encounter struck Fiske as unimaginably romantic, and so The Discovery of America focused much of its attention on the primitive conditions of pre-Columbian native life, 
marveling at the Spanish moderns' unique opportunity to experience "the times of Abraham and Agamemnon" (2: 212). The march of European-American civilization, he judged, had proceeded too far in the centuries since for such time-traveling to happen again. But he did recommend that scholars make haste and study the tribes that remained in the US, before those "most interesting" people were "lost under the influence of white men" (1: viii).

Readers of The Professor's House will immediately grasp how different St. Peter's scholarship must be from Fiske's, not least because the two men are obviously, even diametrically opposed in their first principles. Where Fiske insists that his interpretations of the past have scientific grounding, St. Peter tells his students, "I don't myself think much of science as a phase of human development"; where Fiske celebrates the progress of civilization, St. Peter teaches that humanity was "better off" in earlier times; and where Fiske sees the US as a model for the world because of its incorporated vastness, mechanical efficiency, and white leadership, St. Peter is all but disgusted by it $(67,68)$. Their specific disagreements about the past are harder to know, but Spanish Adventurers is surely a less triumphal study of the European conquerors and a more respectful treatment of the subjugated Native Americans than Fiske's, for two reasons. First, there is the matter of the word "adventurers" in St. Peter's title, a term that had pejorative connotations in scholarship at the time. ${ }^{2}$ More importantly, the project has been meaningfully shaped by Tom Outland, St. Peter's broadminded friend who traveled with him in the Southwest during his writing years, who expressed a "filial piety" for America's indigenous peoples, and, beginning with the fourth, critically respected volume of Spanish Adventurers, helped change the course of its history (250). ${ }^{3}$

If Cather is mostly silent about the contents of St. Peter's history, she does note two hallmarks of its style and narrative method: it is "simple" and "inevitable," and it grows "more simple and inevitable" as it goes on (259). These adjectives can only shed so much light on Spanish Adventurers and the experience of reading it, and when investigated, they even leave the impression that St. Peter's work is something of a paradox. But they also reveal a great deal about the new form of historical endeavor that Cather was imagining in The Professor's House and preparing to embark on in Death Comes for the Archbishop - a form that would combine the techniques and methods of various arts and disciplines, and would be ideally suited to novelists such as herself.

The "simple" Spanish Adventurers appears to say much by saying little, but what precisely is the nature of its simplicity? Looked at one way, there is nothing remarkable about learning that St. Peter writes in this manner, for he would have done his work in 
an era when academic historians were applying scientific methods and techniques to the study of the past and were searching for a precise, pared-down style to match. As Peter Novick has shown, virtually all the leading US historians of that time hoped their books might assume "the mantle of science," so they "consistently distanced themselves from, and disparaged, 'history as literature,' 'history as art"' $(33,40)$. In earlier works of US history, "the individual fact was fondled, celebrated, bejeweled, and dressed in layers of adjectives," but by the turn of the twentieth century, "it was the plain and the unadorned fact which was à la mode" (43). It should therefore come as no surprise that the ever-simplifying St. Peter gains the respect of his peers at roughly the same rate that he cuts words from his books.

Yet this explanation for St. Peter's "simple" style does not quite satisfy, and not only because of his distaste for "science as a phase of human development." St. Peter, after all, is said to have begun writing in this way "largely because of Outland," whom he met and was inspired by when about halfway finished with Spanish Adventurers (259). Outland's remarkable intellect showed the historian how to "experience afresh things that had grown dull with use," and he may have taught him new principles of composition too, insofar as Cather reveals the young man's writing to have been every bit as "simple" as St. Peter's eventually becomes (258). Outland rather conveniently grows up to be an academic scientist, yet there is something more than the sterile hygiene of the laboratory in his prose. At the end of The Professor's House, St. Peter is editing some of Outland's field notes for publication, and as he reads he observes that

If words had cost money, Tom couldn't have used them more sparingly. The adjectives were purely descriptive, relating to form and colour, and were used to present the objects under consideration, not the young explorer's emotions. Yet through this austerity one felt the kindling imagination, the ardour and excitement of the boy, like the vibration in a voice when the speaker strives to conceal his emotion by using only conventional phrases. (262)

Students of modernist aesthetics will notice that Outland is as much an artist as an empiricist here. In his commitment to excision, objectivity, and emotional reserve, Outland achieves the kind of understated narrative intensity eventually associated with some of the most famous works of experimental US literature. But he is surely even closer in his writing to Cather herself, who in 1922 had published an essay arguing that the highest art tends toward "processes of 
simplification" and who sought to leave a sense for "the inexplicable presence of the thing not named" in her own novels ("Novel Démeublé" 836, 837).

Readers are thus left to wonder whether St. Peter wrote more like a "simple" scientific historian or a "simple" literary artist after he met Outland, but that is not the only problem that Spanish Adventurers presents. The history is also described as growing more "inevitable" over time, and the word raises fundamental questions about St. Peter's methodology and his relationship to his material. In describing the completed Spanish Adventurers this way, Cather points to the project's striking genesis, which came about when St. Peter was a young man travelling in Europe. Sailing by the Sierra Nevadas one day, the budding scholar

lay looking up at them from a little boat riding low in the purple water, and the design of his book unfolded in the air above him, just as definitely as the mountain ranges themselves. And the design was sound. He had accepted it as inevitable, had never meddled with it, and it had seen him through. (105)

It is tempting to read this as a moment of clarity, in which St. Peter suddenly discovers the underlying, true course of Spanish history, and hence the course of his book. To know earlier times in some immediate sense, without having to resort to interpretation; to have a view of the past, as Leopold von Ranke had put it in an influential aphorism, as it actually happened; and to show that history was as "definitely" knowable as the visible contours of the natural worldthese were in many ways the highest aims of scientific history at the turn of the twentieth century. For St. Peter, to see a historical narrative as "inevitable" in this moment might therefore be to see it correctly, and Cather may once again be alluding to empirical, scientific dimensions in his writing.

Yet St. Peter's "inevitable" book is profoundly unscientific, and for a simple reason: the "design" for Spanish Adventurers has preceded its research, thus violating a fundamental tenet of scientific history. As Novick has explained, turn-of-the-century scientific historians hoped that the profession would one day produce a "definitive, objective, re-creation of the historical past," clear as the Sierra Nevadas had been to the young St. Peter (39). That achievement, however, would necessarily be a collective one, and individual scholars were expected to spend their time gathering useful specimens rather than trying to envision grand wholes. Historians who helped assemble "a body of reliable atomistic facts" might contribute to the eventual realization of historical truth, but that truth could not be known in advance, and hypotheses were to be avoided because they went "beyond what could 
be directly observed" $(34,39)$. By holding to an "inevitable" design throughout his research, then, St. Peter opens himself to the charge that he has imposed that design upon his materials. As for Spanish Adventurers, it may be as much an aesthetic narrative as a scholarly one, and it may once again be closer to the kinds of writing that Cather associated with great artists. ${ }^{4}$ For just as simplicity was a value that Cather praised in literature, so too was inevitability, as when she described Sarah Orne Jewett's The Country of the Pointed Firs (1896) as having a design "so happy, so right, that it seems inevitable; the design is the story and the story is the design" ("Miss Jewett" 849).

In the end, speculating about the unreadable words of Spanish Adventurers is less important than recognizing the project's intriguing tensions, surprising convergences, and crucial implications for Cather's own writing. St. Peter's work is celebrated by historians and yet is "quite different" from what they would publish themselves; it blends the factual imperatives of history with the imaginative vision of art without being reducible to either; and it suggests a form in which the past, the written word, and lived experience can merge with and inform one another. Such a complex, unconventional history might be unrealizable in any practical sense, but the affinities between St. Peter's expansive scholarship and Cather's historical fiction are clear. The Professor's House was itself the unique product of Cather's research, creativity, and travels into "the great dazzling South-west country" (259)..$^{5}$ And if she would not say too much about St. Peter's history in her novel, it may have been because she was about to write something like it in Death Comes for the Archbishop.

Literary scholars have sometimes wondered whether Cather's fictional professor was a portrait of anyone other than the artist who created him. Southwestern history was a small but coherent academic enterprise in the early twentieth century and, like any other, it had its share of leading figures and unconventional writers. But no one has yet considered how well St. Peter's career accords with that of the universally recognized authority in the field at the time: Herbert Eugene Bolton, the era's most respected historian of Spanish North America and the father of what would eventually come to be known as "hemispheric" history.

Bolton spent most of his working years at the University of California, Berkeley, and he dedicated them to revising a US history that he believed had been "written almost solely from the standpoint of the East and of the English colonies" (qtd in Bannon 89). In his books, lectures, and extraordinarily popular classes, Bolton argued 
that the nation's founding had begun with the Spanish conquest of the New World instead, and he pushed against the reigning Fiskean prejudices of his profession. He saw no special talents or superiority in the British, discounting their achievements as colonizers and calling them "late comers" to the continent (Wider Horizons 7). "We Saxon Americans today may regard our respective countries as Promised Lands, reserved for God's chosen peoples," he observed in his 1932 presidential address to the American Historical Association, "But our Saxon ancestors froze and starved in them primarily because their Hispanic contemporaries were firmly intrenched in the sunnier climes" (Wider Horizons 6-7). Bolton's students remembered a professor who delighted in tweaking other historians for their Yankee backwardness: "Mexico City," he was fond of pointing out, "had a great cathedral when Boston was a fishing village" (qtd in Magnaghi 57). Bolton's books also turned American truisms on their head, most radically when suggesting that the nation's first families were in fact its racial and ethnic others. As he noted in one of his most sardonic and widely read works, "It is an oft-repeated boast that tyranny has never thrived on American soil, but it is seldom remembered that the first battles for freedom in this land were fought by the red natives" (Spanish Borderlands 12).

The US, however, was not Bolton's true subject. He was more concerned with larger stories: the history of the North American continent, and even the history of the Western Hemisphere. Nationalist models of US history, Bolton thought, had succeeded merely in creating "a nation of chauvinists," and he found them ill-suited to the global, twentieth-century moment (Wider Horizons 2). As he put it in what would prove to be a mantra throughout his career, the "increasing importance of inter-American relations makes imperative a better understanding by each of the history and the culture of all" (2). In Bolton's view, national histories presumed the integrity of national borders, but borders were generally unimportant, or at least were not important for the reasons they were generally understood to be. Far from divisions between states and their respective histories, they were for Bolton areas of maximal diversity, heterogeneity, and mutuality. "Most present-day political boundary lines in America are of recent origin," he wrote, and "culture and commerce quite generally ignore them" (History iii). Bolton therefore recommended studying the US in relational terms rather than in isolation, as an entity that had been shaped by several contending European and Native powers during an extended, centuries-long founding. Doing so, he thought, would reveal that the key phases in its history had been "common to most portions of the entire Western Hemisphere" and would ultimately demonstrate that "much of what has been written of each national history is but a thread out of a larger strand" (Wider Horizons 3). 
Bolton and Cather were contemporaries - he was born three years before she-and the similarities between the real scholar and the one in The Professor's House were striking enough that a historian who read the novel in the 1920s or 1930s could suppose that it was an academic roman à clef. Bolton and St. Peter are superficially alike in several ways: as of 1925 , both were recognized leaders in the same field; both had published eight books; both had edited primary documents for publication; and both had given lectures at the Lowell Institute in Boston (where Bolton ruffled feathers by discussing "New England provincialism" in the winter of 1920-1921) (Bannon 138). More significant are their shared scholarly convictions. Both historians refuted Fiske in their works, thus dissenting from the academy's persistent racial and ethnic biases. Both were known for traveling to the Southwestern scenes of their histories: just as St. Peter has "been over every mile" of a subject's trail on horseback, so too did Bolton lead expedition parties to landmarks formerly known only "in myth and legend" (Professor's House 259; Bannon 46). In an especially significant confluence given the subject of Death Comes for the Archbishop, both saw the Catholic Church as a central actor during the Spanish conquest.

Did Cather ever read Bolton's work? There is no record of it, and her projects by no means required her to. Cather had access to any number of other scholarly models, and in the 1920s, she consulted several histories of Spanish America that, like Bolton's, were refreshingly free of Anglo-Saxon prejudice. The more relevant question is whether she could have managed to overlook him. Cather was a persistent researcher during the historical phase of her career and frequently solicited recommendations from the staffs at the New York and Denver public libraries, both of which had Bolton's books in their holdings. ${ }^{6}$ She also read works that conspicuously cited him. Her parents owned Frederic L. Paxson's History of the American Frontier (1924), which commended Bolton for journeying to Mexican archives "covered by the dust of generations" and founding a "distinctive school" of Southwestern history; an underlined sentence in the Cather family copy terminates in a footnote referring to the Bolton-edited Father Kino's Memoirs of 1919 (143, 303, 361). ${ }^{7}$ And when Cather read George Wharton James's New Mexico, the Land of the Delight Makers (1920), she might have seen Bolton praised for the "incalculable benefit, and illimitable interest" of his scholarship (350). Even if the connections between Bolton and St. Peter cannot be more than speculative, it is hard to imagine that the thorough, widely read Cather failed to identify the most important Southwestern historian of her day.

Of course, the story of Cather's historical fiction would in many ways be more dramatic if she never discovered Bolton. It 
would then be a tale of unconsciously shared intellectual purpose, and a profound demonstration of fiction's capacity for historical investigation: a distinguished novelist and a distinguished historian, each contemplating similar issues and reading many of the same books, arrive at an unusual yet mutual conclusion, and one of them, in a moment of literary fancy, dreams the other into existence. The question of influence, moreover, can run both ways, for while we cannot know whether Cather read Bolton, we do know that he read her. In a 1929 essay, Bolton argued that one of the great, continuing legacies of the Southwestern past had been "the Hispanic appeal to the imagination," naming Cather as one of several writers who "have shown that these inter-American bounds have a Spain-tinged folklore as rich as that of the Scottish border embalmed by Sir Walter Scott" (Wider Horizons 102). One wonders, then, how literary the field of hemispheric history has been ever since its inception and how formative The Professor's House and Death Comes for the Archbishop might have been to it.

If Bolton admired Cather's "inter-American," "Spain-tinged" fiction, it was surely because he had read Death Comes for the Archbishop and seen some of his arguments about the nation's fluid boundaries and multinational foregrounding confirmed there. The novel begins in 1848 and chronicles four decades in the life of Father Jean Marie Latour, a French Catholic sent to preside over a diocese in the recently taken, archetypally Boltonian borderland of New Mexico. Cather's European protagonist puts down roots in soil that had formerly been Mexican; he meets a variety of Hispanic and Native characters; and he only occasionally encounters white, lifelong citizens of the US. Along the way, Latour comes to appreciate that while the occupation of New Mexico has only just begun, the land itself has a long and violent past. He hears several accounts of Spain's rule there-including tales of enslavement, rebellion, and extermination-and he ultimately concludes that the territory "had had more than its share of history" because it had "been too tempting to white men" in earlier times (129). Put simply, Death Comes for the Archbishop is a twentieth-century story of a nineteenth-century émigré confronting the three centuries of international conquest that have preceded him.

Like the layers of a rock formation, past events can seem coterminous with present ones in Death Comes for the Archbishop, and this immediacy allows Cather to raise two important questions about the novel's historical moment. The first is whether there is any 
meaningful difference between the rising US empire in the nineteenth century and the Spanish one that came before it. The victors now in charge of New Mexico may believe themselves to be unlike the notoriously cruel "adventurers" who took the territory some 300 years earlier, but the defeated Mexicans have a rather different perspective, and the novel repeatedly suggests that the same displacement, cultural loss, and violence that has always attended empire there will continue to haunt the American Southwest.

Cather's second question is how an ethical, historically informed American ought to behave under such circumstances-or to put it another way, whether Latour should dedicate his influence, authority, and understanding of the New Mexican past to resisting the rise of US empire, or to facilitating it. This issue, perhaps more than anything else, has divided scholarship on the novel. For some, Death Comes for the Archbishop celebrates a newly civilized Southwest, with Latour figured as a benevolent, respectful father who brings order to New Mexico's different peoples and cultures. ${ }^{8}$ Others read it as a stern, even bitter critique of US imperialism, the story of a soldier of the cross who imposes foreign ways upon a conquered land. ${ }^{9}$ Still others have found the novel to dodge politics more or less entirely. In the 1930s, onetime Marxist Granville Hicks dismissed Death Comes for the Archbishop as an escapist's search for a "safe and romantic past" (147), and if modern critics are more generous, some still understand it to be an "evasive text" that raises uncomfortable questions about US power but cannot quite bring itself to examine them (Reynolds 173). ${ }^{10}$

These opposed interpretations are reconcilable, however, for Death Comes for the Archbishop can be read as a study of the ironies and paradoxes that undergirded nineteenth-century US expansion. Cather's America proclaims its commitment to cultural diversity even as it forces the continent's peoples under one flag; it values peace even as it stays on a war footing; and it aspires to make its citizens free even as it enslaves a great many of them. Cather's archetypal American, meanwhile, is the foreign-born Latour, a man who has an unusually strong grasp of the historical antecedents and modern shape of the new US empire, and who nevertheless makes uncomfortable compromises with it throughout his life. His career illustrates how religions serve the state even as they serve the faithful, a subject of great interest to historians of Spanish America in Cather's day. Even more importantly, Latour models a distinctively American way of thinking about empire, and his life offers a view of the national mind as it wrestles - and finds ways to avoid wrestling - with its own contradictions. If Death Comes for the Archbishop strikes some readers as politically "evasive," this is surely because it depicts the act of political evasion itself: Latour's story is one of a country facing the present implications of its violent past, glimpsing the 
limits of its own exceptionalism, and then trying to look away. Cather portrays an empire whose citizens cannot quite admit that they live in one, offering a chilly account of how Americans hope for justice even as they cultivate habits of thought that make them agents of its opposite.

To an extent, Cather was using Death Comes for the Archbishop to enter a longstanding conversation among historians in 1927 and to resituate it in a more US-centric context. Scholars had for decades been debating and reaching entirely different conclusions about the Catholic Church's role in establishing Spain's New World empire, and Cather consulted most of the key titles on the subject while researching her novel. Unsurprisingly, the contemporaneous authority on this subject was Bolton, and if Cather ever read him, his treatment of the Church's complex relationship to the colonizing Spanish state would surely have intrigued her. Bolton argued that Spain's missions had tended to serve a dual purpose in North America from the very beginning, not only working "to Christianize the frontier" but also assisting in "extending, holding, and civilizing it" (Wider Horizons 117). The missions grew increasingly important to the Spanish imperial project over time, particularly after experience "proved that the methods of such conquerors and pacificators as Guzmán and De Soto had worked ill on the whole" (Spanish Borderlands 189). Indeed, Bolton showed, they were so successful that the seventeenth-century Spanish court eventually decided to change its tactics and attempt a "conquest through love" in the New World, emphasizing religious outreach over military strategy (189). This plan had any number of advantages (not the least of which was producing an exploitable labor force for the crown), and Bolton generally approved of it, especially when compared with conditions in the British colonies. However well Bolton might have thought of the Church, though, he was never naïve about its imperial character. "The impression is often given that the missionaries objected to the presence of soldiers," he observed with characteristic dryness, "but as a rule the case was quite the contrary" (Wider Horizons 131).

While Cather was concerned with a different imperial power and a more recent historical period than Bolton, she appears to have been similarly interested in the ways that military conquests can be furthered and consolidated by religious "conquest[s of] love." In Death Comes for the Archbishop, Latour is shown to be bound up with the US government in any number of ways, and his work is broadly useful to the state as it brings its new territories to heel. Latour himself would prefer not to contemplate this, and the novel's understated aesthetic tends to treat the subject in a vague, glancing fashion, which in turn raises the question of whether Cather set out to elicit skeptical, against-the-grain readings of her protagonist. But 
whatever Cather's intentions, it is precisely Latour's inability to conceive of himself as a political actor that makes the novel such a telling study of the nation's imperial past. The general complicity of Americans - and especially of Americans who do not think of themselves as political - in their nation's imperialism may well be the crucial "thing not named" in this historical fiction. And if the novel is not as explicit as Bolton's works had been in stating a thesis, its reticence only intensifies its portrait of a nation in the process of repressing and forgetting the more unsettling truths about itself.

Death Comes for the Archbishop presents Latour as both an enforcer of religious doctrine and a believer in pluralism, a man who hopes to unify peoples of other faiths by conversion rather than by intimidation. Yet the novel frequently suggests that Latour's ideal, cosmopolitan balance cannot be struck in the territory, and his blind spots are seldom more evident than in the moments when he attempts to reach across cultural lines. Perhaps the most striking occurs when Latour visits Ácoma, an ancient, all but impregnable Pueblo cliff city that "had never been taken by a foe but once,- - by Spaniards in armour" (102). That campaign, in 1598, resulted in one of the most notorious massacres in the history of Spanish America, and it was followed by the arrival of Father Juan Ramírez, "a great missionary, who laboured on the Rock of Ácoma for twenty years or more" (106-7). Upon ascending into the city, Latour marvels at the construction that Ramírez oversaw two centuries before and reflects on the wisdom of leading by spiritual example rather than by force. "Powerful men they must have been, those Spanish Fathers, to draft Indian labour for this great work without military support," he thinks (107).

The distinction between military and religious rule, however, was not so great in Ácoma as Latour might like to believe, and whatever kindness the church may have shown there, it was founded upon the subjugation of the Pueblos - as the novel portentously observes, the city's centerpiece building is an "old warlike church" (106). Cather underlines this further when Latour attempts to lead a service there, only to encounter an outwardly obedient people who seem to resist him in every way that matters. Here Latour realizes the limits, even the futility of his ecclesiastical power:

He felt as if he were celebrating Mass at the bottom of the sea, for antediluvian creatures; for types of life so old, so hardened, so shut within their shells, that the sacrifice on Calvary could hardly reach back so far. Those shell-like backs behind him might be saved by baptism and divine grace, as undeveloped infants are, but hardly through any experience of their own, he thought. When he blessed them and sent them away, it was with a sense of inadequacy and spiritual defeat. (106) 
This is a disturbing experience, both for Latour and for readers inclined to think of him as a mostly unprejudiced man. Faced with and perhaps provoked by recalcitrant, unreachable Native Americans, Latour falls back on Fiskean expressions of evolutionary chauvinism. Yet if he feels cultural or religious superiority to these "antediluvian creatures," he is still shadowed by "a sense of inadequacy and spiritual defeat," and it is Cather's decision to trouble Latour here that most distinguishes her historical account of Ácoma. In her research, she had seen the Spanish described as humane conquerors of the cliff city and the Pueblos condescended to as primitives who eventually benefited from Christ's teachings. In the novel, however, the old civilizational conflicts and challenges to Catholic authority remain, grimly suggesting that it will take more than religious teaching to impose orthodoxy on this rock.

At the same time that Latour is failing to move New Mexicans at Ácoma, the US government is succeeding at bringing the larger territory under state control. In doing so, it relies on some of the same techniques that the Spanish conquerors had used, namely, legally sanctioned enslavement and the military expulsion of native peoples. None of this is confined to the novel's background: indeed, some of Cather's pivotal scenes oblige Latour to witness and even participate in forceful applications of US power. He does not wish to be involved in any of these cases, and each time, he advises the subdued to resign themselves to that which cannot be resisted, while privately hoping for a better future. But even as Latour retains his piety, he becomes a symbol of unhappy worldly realities, illustrating how religion can help pave the way for belligerent states and evincing a pernicious tendency among nineteenth-century Americans to defer the moral questions that attended their country's westward expansion.

The most profound of these moments occurs in 1859, when Latour meets Sada, an elderly Mexican slave. One winter night, she leaves the freezing woodshed where she sleeps and takes refuge in Latour's church. He discovers her there, and while Sada does not ask him to help secure her freedom, he is forced to make a reckoning nonetheless. The bonds keeping Sada in slavery, Cather reveals, are relatively weak: her masters are transplants from Georgia, and because they have no legal title to her, they fear that "their charwoman might escape from them and find asylum among her own people" in New Mexico (225). But even though Sada's liberty has never been far out of reach in the Southwest, and even though Latour has in the past been asked by other clergy to "secure the consolations of religion" for her, the bishop has always thought it "inexpedient to antagonize" her Protestant owners, given that they take "every occasion to make trouble for the Catholics" and enjoy bullying his parishioners on Sundays (226). 
Latour does not encourage Sada to continue her escape. Instead, he assures her that "in the year to come, and during the Novena before Christmas, I will not forget to pray for you," which leads him to experience an epiphany at once stirring and disturbing:

Never, as he afterward told Father Vaillant, had it been permitted him to behold such deep experience of the holy joy of religion as on that pale December night. He was able to feel, kneeling beside her, the preciousness of the things of the altar to her who was without possessions; the tapers, the image of the Virgin, the figures of the saints, the Cross that took away indignity from suffering and made pain and poverty a means of fellowship with Christ. Kneeling beside the much enduring bond-woman, he experienced those holy mysteries as he had done in his young manhood. He seemed able to feel all it meant to her to know that there was a Kind Woman in Heaven, though there were such cruel ones on earth. (227-28)

Cather's frequently ambiguous treatment of Latour is sustained especially well in this act, which can be read as both a surface expression of faith and a deeper abrogation of responsibility. The contrast between Sada's spiritual emancipation and the material one she is not to receive is so obvious as to be overdetermined: it is all too easy to respond that the Cross is not the only instrument capable of delivering her from "suffering," "pain," and "poverty," or that her abusers "on earth" can be confronted there, not simply forgotten while communing with the "Kind Woman in Heaven." Less clear is the degree of control Latour has over his own thoughts, with Cather twice noting that he is "able" to feel the spiritual grandeur of Sada's abjection, resulting in a tension between what God might have "permitted" him to understand and what he might have convinced himself of. Finally, there is the challenge of discourse that shadows much of the novel: it is difficult to locate the boundary separating Latour's testimony from Cather's more detached account of the scene, to say nothing of the difference between what Sada feels and what Latour reports her to believe. Exacting readers are thus invited to see this experience of "holy joy" as a poetic but ultimately evasive flight from sociopolitical realities, and when Cather writes a few lines later that the "beautiful concept of Mary" has touched Latour, they might wonder what a less abstracted Mary would have encouraged him to do (228).

The ultimate workings of Latour's conscience remain unknowable in this scene, with Cather suggesting contradictions of thought but artfully declining to resolve them. He may believe precisely what he says and feel a spiritual renewal. He may be a hypocrite, cynically invoking religion in order to justify the sacrifice of a slave (a 
conclusion that any reader of Uncle Tom's Cabin, with its many denunciations of professedly Christian slaveholders, could have reached in Latour's 1850s). But he may finally be something even harder to plumb, a man who has found ways to avoid seeing his own most obvious shortcomings. As some of the best histories of midnineteenth century have shown, this meeting occurred in a decade when the US was finally forced to grapple with the intellectual and ethical conundrums that slavery presented, and when Northerners and Southerners both proved adept at finding ingenious, selfdeceiving ways of temporizing with the peculiar institution. The US clergy, moreover, was no exception. Cather based much of Latour's story on the life of the man who actually oversaw the Archbishopric of Santa Fe in those years, and when she read correspondence by him and the other priests in his circle during her research, she probably noticed a letter in which one, having just witnessed a "revolting" slave auction in 1851, finds it "pitiful to see these young girls following their new master" yet also observes that some owners "treat their slaves with great kindness, and in many cases the slaves would not leave the masters even if they were given their freedom" (qtd in Howlett 153). Thus could a simple moral problem become a complex and by extension insoluble one, even in well-meaning American minds. Latour may seem paradoxical in regretting the institution of slavery while still countenancing Sada's enslavement, but he is all too representative of his era.

Latour lives for nearly 30 more years after this encounter, so by the end of his life, the problem of US slavery has been at least partially solved by a war and the passage of time. But the resolution to this and other national injustices only makes his unwillingness to participate in it more glaring, not least because he takes great satisfaction in the eventual outcomes. "God has been very good to let me live to see a happy issue to those old wrongs," he says toward the novel's end (313). "I have lived to see two great wrongs righted; I have seen the end of black slavery, and I have seen the Navajos restored to their own country" (306). The simplicity of these sentences speaks volumes about Latour, and about Americans more generally in their age of empire. In describing himself as an observer of "happy" events, and in figuring the fight against "old wrongs" with actor-less, passive verbs, Latour reveals a mind that feels relief when justice is done but that cannot conceive of being anything more than a bystander to it. There is no betrayal of guilt here, no sign that Latour has been anything less than successful at soothing his conscience with toothless hopes. Nor is there much recognition that the state's acts of benevolence have only come after its acts of subjugation have served their purposes. Latour knows, as his death approaches, that he has "accomplished an historic period," culminating in the irreversible 
territorial perfection of the US (286). The man who "had come with the buffalo" now sees "the railway trains running into Santa Fé"; he understands that the Americans who will follow him will be "men of a different fibre"; and he speculates, in a moment of almost apocalyptic imagination, that the distinctive air of New Mexico, of a sort that can be breathed "only on the bright edges of the world," will "disappear from the whole earth in time" $(285-86,266,288)$. But these observations about history's future course are never accompanied by questions of whether things could have turned out differently.

Having secured its western lands by military aggression, enslavement, and native removal, the US government can afford to be generous in the last decades of the nineteenth century. Consequently, the most evocative symbols of US imperialism in Death Comes for the Archbishop are those that capture both the nation's hope for harmony among its diverse peoples and the immense power that is wielded, often unreflectively, over them. Cather's representative US building is Latour's cathedral, a structure intended to be "worthy of a setting naturally beautiful" but Romanesque in design and definitively closed to indigenous religious practices (183). Her representative US soldier is Kit Carson, a frontiersman who has a Mexican wife yet also leads the "misguided" military campaigns against the Navajo (308). And her representative American ideology can be found in one of Latour's final projects, a collection of the old Southwestern "legends and customs and superstitions" dying out at century's end (289). "He wished now that long ago he had had the leisure to write them down," Cather writes, "that he could have arrested their flight by throwing about them the light and elastic mesh of the French tongue" (289). Like Latour the ecumenical historian, Cather's America looks admiringly upon its varied regions and cultures. But like Latour the hunter, it would never set them free.

\section{4}

Even if Cather never read Bolton, she still answered his call to reconsider US history in light of "the history and the culture of all." But her novel makes its point in negatively formulated ways, casting Latour as a man who learns the lessons of the Spanish empire yet seems unable or unwilling to see them repeating in his own time. Consequently, Cather might at first seem to have avoided some decisive questions: what would an explicitly comparative study of Spanish and US colonialisms actually reveal, and to what extent would they resemble or differ from one another?

Latour's sense of complacent self-satisfaction, however, was precisely what Cather and other likeminded historians would point to as 
the distinguishing feature of America's expansionist project. Death Comes for the Archbishop showed that while nineteenth-century Americans could match the Spanish in meting out violence and depriving people of their liberty, they were unusual, perhaps even exceptional, in regretting that they did such things and in not wanting to think that war and slavery were true reflections of their nation's character. A few of the writers Cather consulted during her research took the same line, finding that US disingenuousness compared poorly with the values that had motivated the Spanish. According to the archeologist Adolph F. A. Bandelier, writing in 1893:

The Spaniards subdued the aborigines openly: we approach them in the disguise of neighbors, pursue them and vex them, often for years at a time, till the desired offence is committed which affords us a pretext for removing or exterminating them.... If we can excuse these and other wrongs, and can justify our whole systematic robbery and destruction of the Indians under the pretence of progress, then we cannot be judges against the Conquest. (280-81)

Bandelier's Southwest thus occupied an uncomfortable position in the US imagination, a place of both inspiring landscapes and barely acknowledged atrocities. "From Santa Clara the view is very beautiful," he concluded, "but a taint of blood adheres to the rocks and to the valley which thence the eye looks down upon" (302).

This was an unpleasant thing for many Americans to hear at the turn of the century, and Bandelier took a risk by so flagrantly trampling on his readers' prejudices. Cather's criticisms were less confrontational and so they probably received a better hearing than they otherwise might have. But if Death Comes for the Archbishop was not as explicit about the history of US violence as other works in the same vein were, it was a great deal more attentive to the ways that Americans kept themselves from seeing the blood on the western rocks. Where Bandelier only alleged that Americans tended to justify and excuse their nation's wrongs, Cather revealed the processes by which they did so, in considerable richness and over the course of a man's life. Hers was an inner history of empire, the story of a nation that would like to think that it is different, that is remarkably good at convincing itself that it is, and that still cannot escape a lingering sense of discomfort. Only a literary form that valued subtlety and suggestion could express such things, one capable of being as elusive and furtive as its subject. Death Comes for the Archbishop succeeds most, then, when it leaves comparably vague feelings of unease in the people who experience it. If a reader finishes its account of Latour's life yet cannot quite shake the sense of having been 
disturbed by something "felt upon the page without being specifically named," Cather's literary history has made its most distinctive point ("Novel Démeublé" 837).

\section{Notes}

1. For a reading of The Professor's House as an autobiographical novel, see James Woodress, Willa Cather: A Literary Life (1987): 3-77.

2. Readers of Cather's novel may remember that this term is also used at one point to disparage St. Peter's Jewish son-in-law, Louie Marsellus (136).

3. As some of the most incisive scholarship on Cather has shown, however, Outland's admiration for Native American culture is hardly free of imperialistic sentiments. See Walter Benn Michaels, Our America: Nativism, Modernism, and Pluralism (1995): 29-40; John Hilgart, "Death Comes for the Aesthete: Commodity Culture and the Artifact in The Professor's House," Studies in the Novel 30.3 (Fall 1998): 377-404; and Benjamin Schreier, The Power of Negative Thinking: Cynicism and the History of Modern American Literature (2009): 85-115.

4. On this subject, see Schreier, who reads St. Peter's history as a determined but ultimately fruitless attempt to reshape the past into a self-evident, redemptive narrative.

5. On the travel and research that informed The Professor's House, see the critical apparatus in the Willa Cather Scholarly Edition of the novel, as well as David Harrell, From Mesa Verde to The Professor's House (1992). On Cather's travel as it pertained to Death Comes for the Archbishop, see once again the Willa Cather Scholarly edition, as well as Melissa J. Homestead, "Willa Cather, Edith Lewis, and Collaboration: The Southwestern Novels of the 1920s and Beyond," Studies in the Novel 45.3 (Fall 2013): 408-41.

6. Cather kept up an especially rich correspondence with Louis Guerber Burroughs of the Denver Public Library in these years, asking for suggestions and assistance with such frequency that she apologized for the demands she was making on her time. The letters are housed in the Willa Cather Collection, Special Collections and University Archives library, Drew University, Madison, New Jersey.

7. The Cather family copy is held by the Willa Cather Foundation in Red Cloud, Nebraska.

8. Readings of Cather that find her presenting Latour's mission in a generally positive light include Anne E. Goldman, Continental Divides: Revisioning American Literature (2000): 111-39; Hilgart, "Death Comes for the Aesthete"; Adam Jabbur, "Tradition and Individual Talent in Willa Cather's Death Comes for the Archbishop," Studies in the Novel 42.4 (2010): 395-420; Michaels, Our America 78-82; and Janis P. Stout, Willa Cather: The Writer and Her World (2000): 230-46.

9. For readings of Cather that see her criticizing Latour's participation in US expansion, see Leona Sevick, "Catholic Expansionism and the Politics of Depression 
in Death Comes for the Archbishop," The Cambridge Companion to Willa Cather (2005), ed. Marilee Lindemann, 191-204; and Joseph R. Urgo, Willa Cather and the Myth of American Migration ( 1995): 167-90.

10. For an interpretation of the novel as fundamentally unconcerned with political history, see Enrique Lima, "Willa Cather's Rewriting of the Historical Novel in Death Comes for the Archbishop," Novel 46.2 (2013): 179-92. On the process by which history is repressed but not quite forgotten in another of Cather's novels, see Blythe Tellefsen, "Blood in the Wheat: Willa Cather's My Ántonia," Studies in American Fiction 27.2 (Autumn 1999): 229-44.

\section{Works Cited}

Bandelier, Adolph F. A. The Gilded Man, and Other Pictures of the Spanish Occupancy of America. New York: D. Appleton and Company, 1893.

Bannon, John Francis. Herbert Eugene Bolton: The Historian and the Man. Tucson: U of Arizona P, 1978.

Bolton, Herbert Eugene. History of the Americas: A Syllabus with Maps. Boston: Ginn and Company, 1928.

- The Spanish Borderlands: A Chronicle of Old Florida and the Southwest. New Haven: Yale UP, 1921. Wider Horizons of American

History. New York: D.

Appleton-Century Company, 1939.

Cather, Willa. Death Comes for the Archbishop. Ed. John J. Murphy. 1927. Lincoln: U of Nebraska P, 1999.

- "Miss Jewett." Willa Cather: Stories, Poems, and Other Writings. Ed. Sharon O'Brien. New York: Library of America, 1992. 849-58.

\section{—. "The Novel Démeublé." \\ O'Brien 834-37.}

The Professor's House. Ed.

Frederick M. Link. 1925. Lincoln: U of Nebraska P, 2002.
- The Professor's House. 1925. N. Pag. TS. Series 1, Box 1, Folder 8. Philip L. and Helen Cather Southwick Collection (MS 077). Archives \& Special Collections, U of Nebraska-Lincoln Lib.

Fiske, John. The Discovery of America, with Some Account of Ancient America and the Spanish Conquest. 2 vols.

Boston: Harcourt, Mifflin and Company, 1892.

Gillman, Susan. "The New, Newest Thing: Have American Studies Gone Imperial?" American Literary History 17.1 (Spring 2005): 196-214.

Hicks, Granville. "The Case against Willa Cather." Willa Cather and Her Critics. Ed. James Schroeter. 1933. Ithaca: Cornell UP, 1967.

Howlett, W. J. Life of the Right Reverend Joseph P. Machebeuf, D.D., Pioneer Priest of Ohio, Pioneer Priest of New Mexico, Pioneer Priest of Colorado, Vicar Apostolic of Colorado and Utah, and First Bishop of Denver. 1908. Denver: Regis College, 1987.

James, George Wharton. New Mexico, the Land of the Delight Makers. Boston: The Page Company, 1920. 
Kaplan, Amy. "'Left Alone with America': The Absence of Empire in the Study of American Culture." Cultures of United States Imperialism. Ed. Kaplan and Donald E. Pease. Durham: Duke UP, 1993. 3-21.

Magnaghi, Russell M. Herbert E. Bolton and the Historiography of the Americas. Westport:

Greenwood Publishing Group, Inc., 1998.
Novick, Peter. That Noble Dream: The "Objectivity Question" and the American Historical Profession. Cambridge: Cambridge UP, 1988.

Paxson, Frederic L. History of the American Frontier, 1763-1893, Students' ed. Boston: Houghton Mifflin Company, 1924.

Reynolds, Guy. Willa Cather in Context. London: Macmillan, 1996. 